\title{
Performance of Nellore young bulls on Marandu grass pasture with protein supplementation
}

\author{
Matheus Henrique Moretti ${ }^{1}$, Flávio Dutra de Resende ${ }^{2}$, Gustavo Rezende Siqueira ${ }^{2}$, Anna Paula \\ de Toledo Piza Roth'1, Letícia Custódio ${ }^{3}$, Marcella de Toledo Piza Roth'1, Wellington da \\ Costa de Campos ${ }^{3}$, Luiz Henrique Ferreira ${ }^{3}$
}

\footnotetext{
${ }^{1}$ Post-graduate in Animal Science of FCAV/Unesp.

${ }^{2}$ Researcher at APTA. Regional da Alta Mogiana; Guest teacher at FCAV/Unesp.

${ }^{3}$ Centro Universitário da Fundação Educacional de Barretos - UNIFEB.
}

\begin{abstract}
The objective of this study was to verify the effect of low-intake supplementation on performance of Nellore young bulls kept on Marandu grass pasture. The experiment was divided in two periods: the dry and rainy seasons. Treatments during the dry period were composed of mineral salt with urea and mineral supplement enriched with true protein and additive. In the rainy period treatments were mineral salt and enriched mineral supplement only. Pastures were evaluated and animals were weighed in both evaluation phases. The variables studied were evaluated in a completely randomized design in a split-plot arrangement, where plots were treatments and subplots were the periods within each phase, considering the types of supplementation as treatments. During the dry season there was no effect of supplement type in the first and second periods of assessment on weight gain of animals, which was of 0.307 and $0.113 \mathrm{~kg}$ /day, respectively. In the third period of this phase there was effect of the type of supplementation on animal performance; animals which received enriched mineral supplement gained $0.600 \mathrm{~kg} /$ day $v s .0 .517 \mathrm{~kg} /$ day for those which received mineral salt with urea. In the rainy season, animals receiving enriched mineral supplement gained more weight than animals receiving mineral supplement: 0.800 and $0.696 \mathrm{~kg} / \mathrm{day}$, respectively. Mineral supplementation with addition of protein and additives provides increases in the weight gains of animals kept at a grazing regime of $15 \%$.
\end{abstract}

Key Words: additive, animal performance, dry season, rainy season, supplement

\section{Introduction}

Nutrition is one of the main factors to be considered in the productive systems of grazing animals, since its use provides the most economic way of rearing cattle sustainably (Reis et al., 2006). For being basically developed in a grazing regime, the Brazilian beef cattle industry must be understood from a complex perspective, which involves different factors within the production system (animal, climate factors, environment, supplements, etc.), assuming great complexity in the generation of the end product, given that its quantity, quality and economic and environmental efficiency will be affected by different interactions.

The nutrient intake of animals kept exclusively under grazing regime most of the times does not meet their nutritional requirements, so animals cannot express their maximum genetic potential for weight gain, and in some cases, they do not even meet their requirements for maintenance, which could lead to weight loss. Thus, a continuous supplementation program is necessary when the objective is to slaughter younger animals, given the limitations present in the basal diet (pasture).

The feed supplementation of grazing cattle consists of an important technology to correct nutritional imbalances that may exist, with the appropriate strategic corrections. The addition of limiting nutrients to the system via supplements at specific times and situations enable the continuous growth of animals and reduction in the production cycle. Therefore, strategies of nutrient supply that make the growth patterns intended viable in the production system should be established.

The post-weaning phase can represent $58 \%$ of the production cycle and should be regarded carefully, since it is the main phase for obtaining the best efficiency in the productive process (Goes et al., 2005), given the fact that if no technology to correct the nutritional deficiencies is adopted over the year this phase can be long, resulting in elevated animal age at slaughter. Thus, in a production system that aims at high efficiency rates, it is essential that negative growth phases be eliminated, providing conditions for the animal to develop normally. 
Low-intake supplementation is an attractive option in this scenario. In addition to allowing for the correction of possible nutritional limitations of the pasture, it can carry additives, whose purpose is to act on the gastrointestinal tract of the animal, favoring desirable processes and/or minimizing the undesirable effects. So, this strategy is very interesting from the economic point of view, because one can obtain increased animal weight gain with a low investment.

Given the above, the objective of the present study was to verify the effect of low-intake supplementation on performance of Nellore young bulls kept on Brachiaria brizantha $\mathrm{cv}$. Marandu pasture during the dry and rainy seasons.

\section{Material and Methods}

The experiment was conducted in the Research Unit of Pólo Regional de Desenvolvimento Tecnológico dos Agronegócios, located in the municipality of Colina, SP, Brazil, in the period from June 30, 2008 to March 26, 2009. The research unit is located at coordinates $20^{\circ} 43^{\prime} 05^{\prime \prime} \mathrm{S}$ latitude and $48^{\circ} 32^{\prime} 38^{\prime \prime} \mathrm{W}$ longitude. The climate of the region (Figure 1) is classified as AW, according to the Köppen classification, and the soil is classified as a sandy dark red Latosol of almost flat topography and good draining capacity.

The experimental area was composed of approximately 20.8 ha, formed in 2008 by a Brachiaria brizantha (Hochst ex. A. Rich.) cv. Marandu pasture. The 20.8 ha were divided in six 3.46 ha paddocks, which were provided with drinkers and troughs for supplementation. In the second fortnight (March 17, 2008), the area was closed so as to accumulate mass for the first phase of the experimental period (dry season); the pasture was fertilized with nitrogen at $50 \mathrm{~kg} / \mathrm{ha}$ with ammonium nitrate in this occasion. In the end of July animals were distributed across the area (July 30, 2008) for

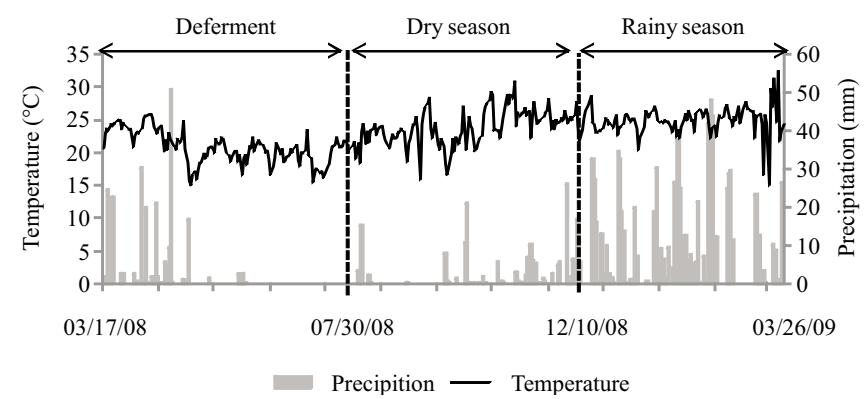

Figure 1 - Climate data (average precipitation and temperature) during the experimental period recorded in the municipality of Colina - SP, Brazil. the beginning of adaptation, which, after weighing marked the start of the first phase of the experiment.

Sixty non-castrated newly-weaned Nellore males at $8 \pm 1$ months of age and average weight $194.4 \pm 30.8 \mathrm{~kg}$ were utilized in this experiment. Animals were identified by earrings and branded with a fire-heated iron on the leg. Other animals of the same origin and management were utilized to adjust the load on paddocks so as to keep the same forage available, between the treatments, isolating the supplement effect. The control of endo (when the EPG exam presented more than 500 eggs/g feces) and ectoparasites (visually) was performed whenever necessary.

The experiment was divided in two experimental phases: the first, which corresponded to the dry season, was conducted between July 30, 2008 and December 10, 2009, comprising 2 periods of 42 days each and a period of 49 days, totaling 128 evaluation days.

The supplements utilized in this phase (treatments) were composed of mineral salt with urea and enriched mineral supplement, which received the addition of true protein and additive (Table 1). Supplements were provided at 0.5 and $1.0 \mathrm{~g} / \mathrm{kg}$ body weight (BW) for the salt with urea and enriched mineral supplement, respectively. The average daily intake of supplement of the lot was monitored daily by collecting the orts from the trough, which after weighed and corrected for dry matter determined the quantity of supplement consumed the day before.

Table 1 - Composition and guaranteed levels of the supplements during the experimental phases (dry and rainy seasons), on a dry matter (DM) basis

\begin{tabular}{|c|c|c|c|c|}
\hline \multirow{2}{*}{$\begin{array}{l}\text { Ingredients }(\mathrm{g} / \mathrm{kg} \\
\mathrm{DM})\end{array}$} & \multicolumn{2}{|c|}{ Dry season } & \multicolumn{2}{|c|}{ Rainy season } \\
\hline & Salt + urea & $\mathrm{w} /$ protein & Mineral salt & $\mathrm{w} /$ protein \\
\hline Cottonseed meal & - & 295.0 & - & - \\
\hline Sunflower seed meal & - & - & - & 378.0 \\
\hline Citrus pulp & - & - & - & 74.7 \\
\hline Urea & 200.0 & 27.0 & - & 25.8 \\
\hline Salinomycin & - & 0.40 & - & 0.50 \\
\hline Virginiamycin & - & 0.50 & - & - \\
\hline Minerals & 800.0 & 669.0 & 100.00 & 516.5 \\
\hline Crude protein & 562.5 & 196.6 & - & 198.9 \\
\hline \multicolumn{5}{|c|}{ Guaranteed levels of the product } \\
\hline Calcium (g) & 140 & 110 & 155 & 110 \\
\hline Phosphorus (g) & 50 & 40 & 80 & 40 \\
\hline Magnesium (g) & 5 & 5.9 & 10 & 5,9 \\
\hline Sulfur $(g)$ & 40 & 20 & 40 & 20 \\
\hline Sodium $(\mathrm{g})$ & 100 & 80 & 130 & 80 \\
\hline Copper (mg) & 780 & 554 & 1350 & 554 \\
\hline Manganese (mg) & 600 & 552 & 1040 & 552 \\
\hline Zinc (mg) & 2900 & 2090 & 5000 & 2090 \\
\hline Iodine (mg) & 58 & 41 & 100 & 41 \\
\hline Cobalt (mg) & 46 & 36 & 80 & 36 \\
\hline Selenium (mg) & 15 & 10.5 & 26 & 10.5 \\
\hline Fluorine (mg) & 500 & 400 & 800 & 400 \\
\hline
\end{tabular}


In the second phase, corresponding to the rainy season, which started on December 10, 2008 and finished on March 26, 2009 , animals remained in the same area of the previous phase. This new experimental phase was composed of 3 periods of 35 days each, in a total of 105 evaluation days. In this phase, treatments were mineral salt (ad libitum) and enriched mineral supplement, supplied at $1 \mathrm{~g} / \mathrm{kg}$ of $\mathrm{BW}$, and the average daily intake was monitored as in the first phase. It is worth mentioning that the enriched mineral supplement in this phase presented some differences in relation to that used in the previous phase (Table 1). In the beginning of phase $2(12 / 31 / 2008)$, the pasture was fertilized with nitrogen at $30 \mathrm{~kg} / \mathrm{ha}$, with ammonium nitrate (Figure 1).

The grazing method utilized in both phases (dry and rainy seasons) was continuous grazing with variable stocking rate. Put-and-take animals were used as described by Mott \& Lucas (1952) so as to keep the same forage availability per animal within paddocks and not favor any of the treatments.

Forage mass was estimated monthly by the double sampling method (Sollenberger \& Cherney, 1995). To obtain the rising plate meter equation, the compressedsward height was measured and forage mass was collected at nine points of the paddock: three at the average height; three at points of higher heights; and three at lower heights. The high and low heights of collection were determined by summing and subtracting the two standard deviations from the average height, respectively, thus comprising $97.5 \%$ of the normal distribution of heights.

The samples collected were taken to a laboratory and weighed for determination of forage masses. The samples generated sub-samples of the whole plant, which were chopped and then dried in an air-circulation oven at $55^{\circ} \mathrm{C}$ for 72 hours and then weighed again for calculation of the dry matter. The three samples collected at the average height were ground in a Wiley knife mill with a $1.0 \mathrm{~mm}$ mesh sieve, and then stored in proper containers for further analysis.

For evaluation of the quantitative and structural components of the forage sward, samples collected at the average height of every paddock were used, as described above. Samples were separated in three fractions: green leaf, green stem and dead material. Subsequently, the different fractions were weighed and dried in an air-circulation oven at $55{ }^{\circ} \mathrm{C}$ for 72 hours and then weighed once more for calculation of the dry matter.

For the estimate of the nutritional value of the diets of animals, forage samples were collected monthly by the method of grazing simulation, based on the manual collection of forage after previous observation of the grazing habit of animals. The samples obtained, totaling 2 per paddock, were taken to the laboratory and homogenized, resulting in two composite sub-samples which were weighed and dried in an air-circulation oven at $55{ }^{\circ} \mathrm{C}$ for 72 hours and weighed again for the calculation of the dry matter. These dried samples were ground in a Wiley knife mill with a $1.0 \mathrm{~mm}$ mesh sieve and then stored in proper containers for further analysis.

Bromatological analyses of whole plant and simulated grazing samples were performed in the Laboratory of Analysis of Vegetal and Animal-Origin Products (LAPROVA), located at APTA - Alta Mogiana. Contents of dry matter (DM) and crude protein (CP) were determined according to the methods described by Silva \& Queiroz (2002). Neutral detergent fiber (NDF) and acid detergent fiber (ADF) contents were assessed via the sequential method, described by Van Soest \& Robertson (1991), in which samples were subjected to digestion in a detergent solution for 40 minutes in an autoclave at $110{ }^{\circ} \mathrm{C}$ and $0.5 \mathrm{~atm}$ (Deschamps, 1999). In the samples of simulated grazing, fractions $\mathrm{B} 3$ and $\mathrm{C}$ of the crude protein were also determined according to Sniffen et al. (1992) and the in vitro dry matter digestibility (IVDMD) according to Goering \& Van Soest (1970).

To determine the weight variation animals were weighed at time zero (beginning of experiment - July, 2008) and then at every 42 days in the dry period and 35 days in the rainy period, always after a previous solid and liquiddeprivation period of 16 hours.

The data were analyzed in a completely randomized design with repeated measures over time. Authors adopted a mixed model with fixed effect of supplement type, period and their interactions; and random effects of animal in the case of performance evaluation or paddock in the case of evaluations of the forage, nested into type of supplement and residue utilizing procedure MIXED of SAS (Statistical Analysis System, version 9.0). An analysis of error structures was performed, investigating the structures for every one of the variables studied and the best was chosen according to the Bayesian Information Criterion (BIC). Effects of supplement, periods and their interactions were studied considering the matrix of error structure chosen. When significant, means were compared by using the least significant difference test of Fisher (feature DIFF of command LSMEANS). The variables with significant interactions were deployed with command SLICE of LSMEANS. In all analyses, significance was declared at $\mathrm{P} \leq 0.05$. 


\section{Results and Discussion}

In the beginning of the experiment, the sward mass was high, with $10,060 \mathrm{~kg} \mathrm{DM} / \mathrm{ha}$, which was a result of the period of pasture deferment (March to June/2008). However, this mass was composed of an elevated proportion of dead material and green stem, which were 617.6 and $283.5 \mathrm{~g} / \mathrm{kg}$ $\mathrm{DM}$, respectively, and only $99.1 \mathrm{~g} / \mathrm{kg} \mathrm{DM}$ of green leaves (Table 2).

The major obstacle in management during the deferment period are the environmental conditions, which can affect mass accumulation. In the present study, due to the great precipitation in the first 40 days of deferment (March 17 to April 25), $207.3 \mathrm{~mm}$ (Figure 1), plant growth and consequently mass accumulation were favored. The latter is desirable; however, if too intense, it can compromise the utilization of the mass obtained because of the drop in nutritional value and losses by lodging. According to Santos et al. (2008), the ratio between the green leaf blade and green stem masses decreases linearly as the deferment period advances, which indicates that the structure of the pasture deferred for a longer time is detrimental to animal intake.

From a given stage of development tillers started to compete for light, elongating their stems, resulting in shading of the lower parts, which caused tiller death, increasing the participation of these components (green stem and dead material) in the accumulated mass (Figure 2), which compromised the quality of the mass obtained, since these components have elevated lignification.

According to Santos et al. (2010), the green stem mass increases linearly on pastures deferred for a longer period, which was observed in this experiment. According to them, because the sward starts to intercept $95 \%$ of the incoming light (critical leaf area index), tillers begin a competition for light; as a consequence, stems elongate, thus characterizing the tiller size/population density compensation.

The forage mass characteristics in the beginning of the experiment had an influence on pasture quality all through the experimental period and on animal performance as well. In all periods of both phases (dry and rainy), there was elevated percentage of dead material, greater than $600 \mathrm{~g} / \mathrm{kg}$ DM during the dry season and higher than $300 \mathrm{~g} / \mathrm{kg}$ DM during the rainy season (Figure 2 and Table 2). This elevated level of dead material was a response to the low stocking rate during all the experiment associated with low nitrogen fertilization in the beginning of the rainy season (30 kg N/ha).

The accumulation of dead material, especially dead stem, during the dry period, was probably favored by the type of forage consumed by animals. According to Carvalho Filho et al. (1984), animals perform a selective grazing by parts of the plant (green leaves preferably), according to their availability, accessibility, acceptability and nutritional value, thus promoting accumulation of fractions of lower acceptance on the pasture. Thus, the pasture quality during the rainy period was compromised by the elevated residue of dead material at the end of the dry season $(711.2 \mathrm{~g} / \mathrm{kg} \mathrm{DM})$.

As a consequence of the low proportion of green leaves during the rainy period, the stocking rates were low: 1.60 to $1.93 \mathrm{AU} / \mathrm{ha}$ (Table 2). Even though this was not the objective

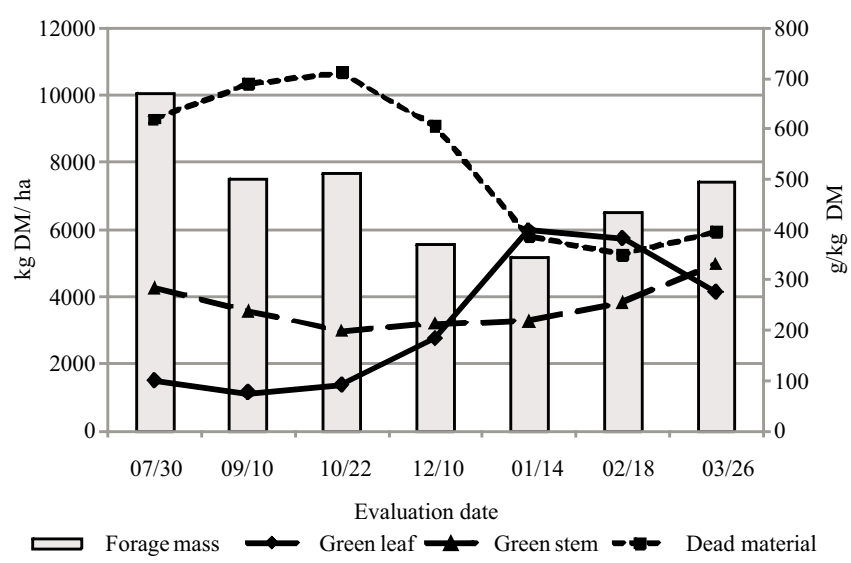

Figure 2 - Variation of sward components of Marandu grass pasture during the experimental period in the dry season $(07 / 30 / 2008$ to $12 / 10 / 2009)$ and rainy season $(12 / 10 / 2008$ to $03 / 26 / 2009)$.

Table 2 - Variation of sward components of Marandu grass pasture during the experimental period (dry and rainy seasons)

\begin{tabular}{|c|c|c|c|c|c|c|c|c|}
\hline \multirow{2}{*}{ Variable } & \multicolumn{4}{|c|}{ Dry season } & \multicolumn{3}{|c|}{ Rainy season } & \multirow{2}{*}{ SEM } \\
\hline & Jul 30 & Sep 10 & Oct 22 & Dec 10 & Jan 14 & Feb 18 & Mar 26 & \\
\hline Forage mass (kg DM/ha) & $10060 \mathrm{a}$ & $7483 b$ & $7692 b$ & $5549 \mathrm{de}$ & $5170 \mathrm{e}$ & $6488 \mathrm{~cd}$ & $7426 \mathrm{bc}$ & 413.9 \\
\hline Green leaf (g/kg DM) & $99.1 \mathrm{~d}$ & $74.3 \mathrm{e}$ & $90.4 \mathrm{de}$ & $182.7 \mathrm{c}$ & $398.3 \mathrm{a}$ & $382.7 \mathrm{a}$ & $275.6 b$ & 16.18 \\
\hline Green stem (g/kg DM) & $283.5 b$ & $237.4 \mathrm{c}$ & $198.4 \mathrm{c}$ & $212.6 \mathrm{c}$ & $216.8 \mathrm{c}$ & $254.0 \mathrm{bc}$ & $330.2 \mathrm{a}$ & 21.28 \\
\hline Dead material (g/kg DM) & $617.6 b$ & $688.3 \mathrm{a}$ & $711.2 \mathrm{a}$ & $604.7 b$ & $384.9 \mathrm{c}$ & $349.5 \mathrm{c}$ & $394.2 \mathrm{c}$ & 34.87 \\
\hline Leaf:stem ratio & $0.35 \mathrm{~d}$ & $0.33 \mathrm{~d}$ & $0.47 \mathrm{~d}$ & $0.87 \mathrm{c}$ & $1.92 \mathrm{a}$ & $1.54 \mathrm{~b}$ & $0.84 \mathrm{c}$ & 0.120 \\
\hline Stocking rate (AU/ha) & $1.42 \mathrm{c}$ & $1.55 \mathrm{c}$ & $1.63 \mathrm{bc}$ & $1.60 \mathrm{bc}$ & $1.73 b$ & $1.93 \mathrm{a}$ & $1.93 \mathrm{a}$ & 0.007 \\
\hline
\end{tabular}

SEM - standard error of the mean.

Means followed by the same letter are not different at $5 \%$ significance. 
of the present study, the importance of management during pasture deferment, as well as its use during the dry period on the efficiency of the grazing system is clear.

The daily intake of both supplements was variable during the dry season, which could be an indicator that animals did not appreciate them very much, once they did not consume them completely (Figure 3 ).

The average daily intake of both supplements varied according to the evaluation period; the intake of mineral salt with urea showed $0.5,0.4$ and $0.3 \mathrm{~g} / \mathrm{kg} \mathrm{BW}$, and the enriched salt, $0.9,0.8$ and $0.6 \mathrm{~g} / \mathrm{kg} \mathrm{BW}$, respectively, in the first, second and third periods of the dry season (Figure 3). The daily monitoring of supplement intake allows us to make some inferences on the association of the higher or lower supplement ingestion and the quanti-qualitative characteristics of the forage sward. Animals decreased their supplement intake mainly after the occurrence of rainfall, which was probably a consequence of the grass regrowth, which led them to consume emerging leaves and consequently reduce supplement intake (Figures 2 and 3 ).

During the dry period, there was interaction $(\mathrm{P}<0.05)$ between treatments and evaluation periods (Table 3 ) on the daily weight gain of animals. In the first and second periods of the dry season there was no difference $(\mathrm{P}>0.05)$ in weight gain as a function of enriched mineral supplementation or

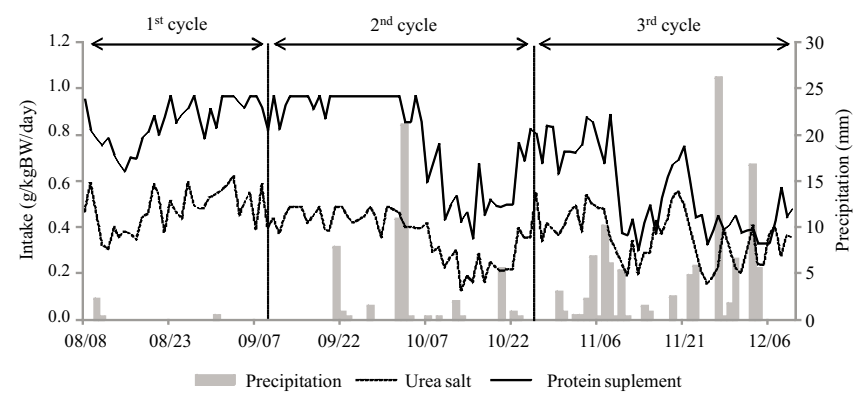

BW - body weight.

Figure 3 - Average intake (g/kg BW.day) of supplement by Nellore steers during the dry period on a Marandu grass pasture according to the type of supplementation. supplementation enriched with urea, which were 0.307 and $0.113 \mathrm{~kg} /$ day on average, respectively. In the third period there was effect of supplementation type on animal performance; the animals that received enriched mineral supplement gained $0.600 \mathrm{~kg} /$ day $v s .0 .517 \mathrm{~kg} /$ day for those which received mineral salt with urea.

In the first period of the dry season $(07 / 30 / 08$ to 09/10/08), the animal performance can be associated with the forage mass available for grazing, which was composed of a high percentage of dead material $(617.6 \mathrm{~g} / \mathrm{kg} \mathrm{DM})$ and presented high availability: $15.35 \mathrm{~kg} \mathrm{DM} / \mathrm{kg}$ of body weight (BW), which possibly allowed animals to select the forage according to the higher forage availability, which, associated with supplementation, resulted in the gains observed (Table 3).

Analyzing the chemical composition of the whole plant in the first period of the dry season, we can notice that $\mathrm{CP}$ varied from 28.7 to $26.3 \mathrm{~g} / \mathrm{kg}$; however, because of the selective grazing capacity of the animal (samples of simulated grazing), the likely proportion consumed showed $51.1 \mathrm{~g} / \mathrm{kg} \mathrm{CP}$ (Figure 4). Even with this selectivity, the diet consumed by the animal presented $\mathrm{CP}$ values below the minimum of $80 \mathrm{~g} / \mathrm{kg}$ on a dry matter basis, which is the value required for there not to be decrease in rumen microbial synthesis (Detmann et al., 2009).

Because no difference was verified on weight gain with the supplements utilized in the first dry period, we can assume that the addition of non-protein nitrogen (NPN) with the use of salt + urea was enough for the gains attained, since the inclusion of crude protein and some additives (salinomycin and virginiamycin) in the diet via low-intake protein supplementation did not provide weight gain to animals. Because of the supplement intake (g supplement/ $\mathrm{kg}$ BW.day) and amount of CP in the supplements used (Table 1), the animals that received salt + urea had their total nitrogen intake superior to those receiving enriched mineral supplement, which could result in greater weight gains. However, this higher nitrogen intake was probably compensated by the technological package embedded in the enriched mineral supplementation, wherein the presence of

Table 3 - Performance of Nellore young bulls during the dry period on a Marandu grass pasture according to the type of supplementation

\begin{tabular}{lccccc}
\hline \multirow{2}{*}{ Treatment } & \multicolumn{3}{c}{ Dry season } & Mean & SEM \\
\cline { 2 - 4 } & Jul/30 to Sep/10 & Sep/10 to Oct/22 & Oct/22 to Dec/10 & 0.319 & 0.013 \\
Salt + urea & $0.331 \mathrm{Ab}$ & $0.109 \mathrm{Ac}$ & $0.517 \mathrm{Ba}$ & $0.600 \mathrm{Aa}$ & \\
Protein supplement & $0.284 \mathrm{Ab}$ & $0.117 \mathrm{Ac}$ & 0.559 & & \\
Mean & 0.307 & 0.113 & & \\
SEM & 0.016 & & & \\
\hline
\end{tabular}

SEM - standard error of the mean.

Means followed by the same uppercase letter in the column and lowercase letter in the row are not different at $5 \%$ significance. 
growth promoters (salinomycin and virginiamycin) in the diet favored animal performance in that period.

The lowest weight gains were observed in the second period of the dry season (09/10/08 to 10/22/08): $0.113 \mathrm{~kg} /$ day. The result obtained with supplementation was similar to that found in the previous period. These low gain values contrast the $85.5 \mathrm{~g} \mathrm{CP} / \mathrm{kg}$ obtained with the simulated grazing samples (Figure 4). However, the limiting factor on animal performance in this period is probably explained by the lower intake caused by the changes that occurred in the sward (Table 2). At the end of the first period the forage mass reduced to $7,483 \mathrm{~kg} \mathrm{DM} / \mathrm{ha}$, of which $688.3 \mathrm{~g} / \mathrm{kg} \mathrm{DM}$ corresponded to dead material and $74.3 \mathrm{~g} / \mathrm{kg}$ DM to green leaves. This drop in forage mass resulted in decreased forage availability: from $15.35 \mathrm{~kg} \mathrm{DM} / \mathrm{kg} \mathrm{BW}$ in the first period to $10.72 \mathrm{~kg} \mathrm{DM} / \mathrm{kg} \mathrm{BW}$ in the second, which compromised animal performance. In addition to decrease in forage availability, there was some rainfall in this period $(32 \mathrm{~mm}$ distributed over 5 days), which brought about structural changes in the pasture, given the alterations in the leaf:stem ratio, which at the beginning of the second period was 0.33 and at the end, 0.47 (Table 2).

At this point the digestibility of components of interest assumes importance not only for the quality of the basal diet consumed by the animal (Table 4), but also to the time it will spend searching for food. The animal craves green leaves, especially new ones, spending time looking for this component; however, because its availability is restricted, the total forage intake is affected by the time the animal takes to search for food. In addition to the low availability of green leaves and the high percentage of dead material (average $688.3 \mathrm{~g} / \mathrm{kg} \mathrm{DM}$ ) in the period imply a factor that hampers the access of the animal to this emerging leaf.

The third period of the dry season (10/22/08 to $12 / 10 / 08)$ can be considered a dry-rainy season transition; in spite of the decrease in forage mass, from 7,692 to $5,549 \mathrm{~kg} \mathrm{DM} / \mathrm{ha}$, there was an increase in green leaf availability: from 90.4 to $182.7 \mathrm{~g} / \mathrm{kg}$ DM (Table 2). The increase in the availability of green leaves allows the animal to better select its diet and ingest a better-quality material, which is proven by the values obtained with simulated grazing (129.0 g/kg CP; Figure 4).

At this moment, the type of supplementation started to have an effect on weight gain, since animals that received enriched mineral supplementation gained 0.083 more $\mathrm{kg} /$ day than animals receiving supplementation with urea, in other words, an increase of $16.1 \%$ in weight gain (Table 3 ).

Summarizing results obtained with evaluation of the rumen parameters of animals during the dry period, Detmann et al. (2009) verified the impact of the ammonia nitrogen level on degradation and intake of neutral

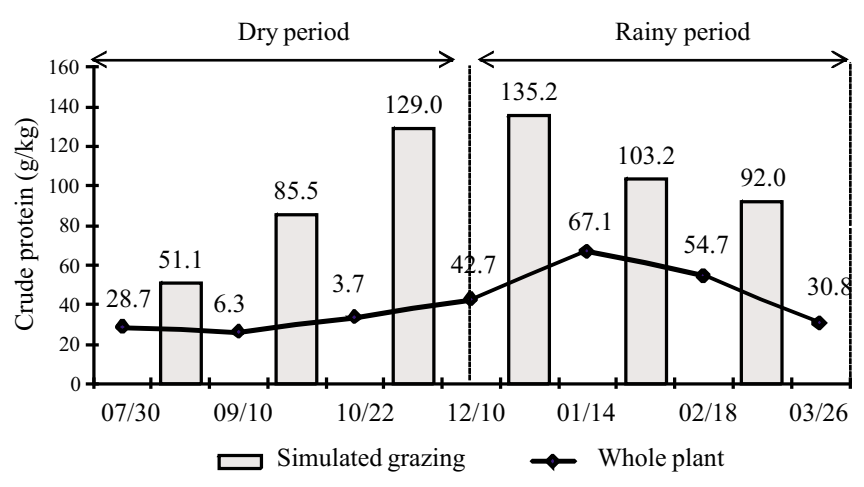

Figure 4 - Variation in the $\%$ of crude protein in the whole plant and simulated grazing samples of Marandu grass throughout the experimental period (dry and rainy seasons).

detergent fiber and concluded that the $\mathrm{CP}$ level of the diet must be $100 \mathrm{~g} / \mathrm{kg}$ for these variables to be maximized. This statement, discussed by these authors, allows for the comprehension of the factors that led to the difference obtained in the third period of the dry season.

Because the $\mathrm{CP}$ content in the diet was not limiting to the rumen microorganisms (Figure 4) - on the contrary, it probably favored the optimization of their activities, causing degradation of the fiber of the basal diet -, the enriched mineral supplement, for having additives in its composition, showed to be superior as regards animal performance. Since the microorganisms are in favorable conditions to their development, there is probably a relative increase in the production of propionic acid as a response to the increase in gram-positive bacteria (effect of additives), which resulted in improvement in the energy efficiency of the diet.

In the following phase, i.e., the rainy season, similarly to the dry period, the supplement intake by animals was variable (Figure 5). The average daily intake of animals that received enriched salt was $0.6,0.8$ and $0.9 \mathrm{~g} / \mathrm{kg} \mathrm{BW}$, respectively, over the rainy period. Higher average daily variations in intake were observed during the first and second periods of this phase, probably due to the greater precipitation during these periods: 262.1 and $409.4 \mathrm{~mm}$, respectively, in relation to the 188.2 of the third period.

Lower forage masses and increase in the percentage of green leaves were observed in the rainy period in relation to the previous phase, the dry season (Table 2), which resulted in increased leaf availability to animals, allowing for a consumption of forage of higher quality, given the $\mathrm{CP}$ contents obtained in simulated grazing samples, which were $132.0,103.0$ and $92.0 \mathrm{~g} / \mathrm{kg}$ in the first, second and third periods of the rainy season, respectively (Figure 4).

Another aspect that indicates improvement in the quality of the material consumed is the increased digestibility of its 
dry matter (Table 4), which is a reflection of the protein fractions. There was also decrease in NDF; however, because lignin was constant, we can affirm that the quantity and quality of fiber reduced (Table 4).

Concerning the daily weight gain, there was no interaction $(\mathrm{P}>0.05)$ between treatments and evaluation periods (Table 5). The animals that received enriched mineral supplementation during the rainy period gained more weight than those fed mineral supplementation: 0.800 and $0.696 \mathrm{~kg} /$ day, respectively. This increase of $14.9 \%$ in weight can be attributed to the CP increase in the diet and the effect of the additive (salinomycin) on the rumen bacteria.

During the dry and rainy periods, the $\mathrm{CP}$ consumed by the animals varied in its composition (Table 6), modifying the more or less digestible fractions. In the beginning of the rainy season, after fertilization, there was an increase in the neutral detergent-soluble fraction $(\mathrm{A}+\mathrm{B} 1+\mathrm{B} 2)$. This increase was probably a result of the nitrogenous fertilization (Figure 1) at the beginning of the rainy period.
However, a big part of this increase is in fraction A, i.e., non-protein nitrogen, since the percentage of fractions B1 and B2 in tropical grasses is lower than fraction A (Balsalobre et al., 2003).

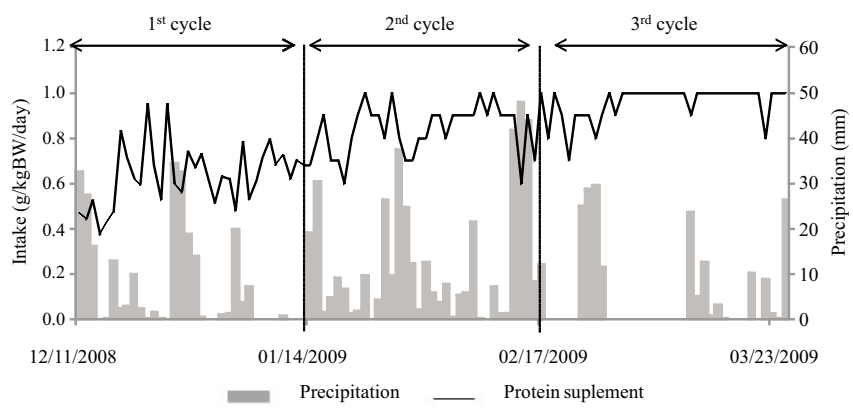

BW - body weight.

Figure 5 - Average intake (g/kg BW.day) of protein supplement by Nellore young bulls during the rainy period on a Marandu grass pasture.

Table 4 - Variation in the chemical composition of samples of simulated grazing of Marandu grass throughout the experimental period (dry and rainy seasons)

\begin{tabular}{|c|c|c|c|c|c|c|c|}
\hline \multirow{2}{*}{ Variable $(\mathrm{g} / \mathrm{kg})$} & \multicolumn{3}{|c|}{ Dry season } & \multicolumn{3}{|c|}{ Rainy season } & \multirow{2}{*}{ SEM } \\
\hline & $\mathrm{Jul} / 30$ to $\mathrm{Sep} / 10$ & $\mathrm{Sep} / 10$ to Oct $/ 22$ & Oct $/ 22$ to $\mathrm{Dec} / 10$ & $\mathrm{Dec} / 10$ to $\mathrm{Jan} / 14$ & $\mathrm{Jan} / 14$ to $\mathrm{Feb} / 18$ & $\mathrm{Feb} / 18$ to $\mathrm{Mar} / 26$ & \\
\hline Dry matter & $627.0 \mathrm{a}$ & $628.0 \mathrm{a}$ & $410.0 \mathrm{~b}$ & $344.0 \mathrm{c}$ & $353.0 \mathrm{c}$ & $380.0 \mathrm{~b}$ & 20.03 \\
\hline Crude protein & $51.0 \mathrm{~d}$ & $85.0 \mathrm{c}$ & $129.0 \mathrm{a}$ & $135.0 \mathrm{a}$ & $103.0 \mathrm{~b}$ & $92.0 \mathrm{bc}$ & 0.750 \\
\hline $\mathrm{NDF}$ & $733.0 \mathrm{a}$ & $726.0 \mathrm{a}$ & $706.0 \mathrm{a}$ & $620.0 \mathrm{~b}$ & $708.0 \mathrm{a}$ & $703.0 \mathrm{a}$ & 14.94 \\
\hline $\mathrm{ADF}$ & $328.0 \mathrm{~b}$ & $353.0 \mathrm{a}$ & $257.0 \mathrm{~d}$ & $256.0 \mathrm{~d}$ & $299.0 \mathrm{c}$ & $312.0 \mathrm{bc}$ & 8.870 \\
\hline Lignin & $54.0 \mathrm{a}$ & $69.0 \mathrm{a}$ & $59.0 \mathrm{a}$ & $56.0 \mathrm{a}$ & $52.0 \mathrm{a}$ & $53.0 \mathrm{a}$ & 0.980 \\
\hline IVDMD (g/g) & $0.657 \mathrm{e}$ & $0.689 \mathrm{e}$ & $0.745 d$ & $0.855 a$ & $0.819 b$ & $0.802 \mathrm{c}$ & 11.17 \\
\hline
\end{tabular}

SEM - standard error of the mean; NDF - neutral detergent fiber; ADF - acid detergent fiber; IVDMD - in vitro dry matter digestibility.

Means followed by the same letter in the row are not different at $5 \%$ significance.

Table 5 - Performance of Nellore young bulls on Marandu grass pasture during the rainy periods according to the type of supplementation: mineral salt or protein supplement

\begin{tabular}{lcccc}
\hline \multirow{2}{*}{ Treatment } & \multicolumn{3}{c}{ Rainy season } & \multicolumn{2}{c}{ SEM } & Fean \\
\cline { 2 - 4 } & Dec/10 to Jan/14 & Jan/14 to Feb/18 & 0.703 & $0.696 \mathrm{~B}$ \\
Mineral salt & 0.565 & 0.820 & 0.764 & $0.800 \mathrm{~A}$ \\
Protein supplement & 0.702 & 0.933 & $0.733 \mathrm{~b}$ \\
Mean & $0.634 \mathrm{c}$ & $0.876 \mathrm{a}$ & 0.027 \\
SEM & 0.027 & 0.027 & 0.024 \\
\hline
\end{tabular}

SEM - standard error of the mean.

Means followed by the same uppercase letter in the column and lowercase letter in the row are not different at $5 \%$ significance.

Table 6 - Variations in the crude protein fractions of samples of simulated grazing of Marandu grass throughout the experimental period (dry and rainy seasons)

\begin{tabular}{|c|c|c|c|c|c|c|c|}
\hline \multirow{2}{*}{ Variable (g/kg) } & \multicolumn{3}{|c|}{ Dry season } & \multicolumn{3}{|c|}{ Rainy season } & \multirow{2}{*}{ SEM } \\
\hline & $\mathrm{Jul} / 30$ to $\mathrm{Sep} / 10$ & $\mathrm{Sep} / 10$ to Oct $/ 22$ & Oct $/ 22$ to $\mathrm{Dec} / 10$ & $\mathrm{Dec} / 10$ to $\mathrm{Jan} / 14$ & $\mathrm{Jan} / 14$ to $\mathrm{Feb} / 18$ & $\mathrm{Feb} / 18$ to $\mathrm{Mar} / 26$ & \\
\hline $\mathrm{A}+\mathrm{B} 1+\mathrm{B} 2$ & $644.0 \mathrm{~b}$ & $649.0 \mathrm{~b}$ & $471.0 \mathrm{c}$ & $716.0 \mathrm{a}$ & $604.0 \mathrm{~b}$ & $734.0 \mathrm{a}$ & 61.57 \\
\hline B3 & $263.0 \mathrm{c}$ & $292.0 \mathrm{bc}$ & $458.0 \mathrm{a}$ & $248.0 \mathrm{c}$ & $330.0 \mathrm{bc}$ & $189.0 \mathrm{~d}$ & 73.84 \\
\hline $\mathrm{C}$ & $94.0 \mathrm{a}$ & $59.0 \mathrm{~b}$ & $71.0 \mathrm{~b}$ & $36.0 \mathrm{c}$ & $66.0 \mathrm{~b}$ & 77.0ab & 25.82 \\
\hline
\end{tabular}

SEM - standard error of the mean.

Means followed by the same letter in the row are not different at $5 \%$ significance. 
Assuming an elevated participation of highdegradability components in the protein profile and that dry matter digestibility is high in the rainy period (Table 4), we can presume that the rumen would be in imbalance, since even with a high rumen dry matter degradability coefficient the time for this energy to become available would be incompatible with the high degradation of the NPN of the forage, which would lead to different moments of release of each one of these products in the rumen, causing reduction in the microbial assimilation of nitrogen.

According to Detmann et al. (2009), the product of the relations of CP and DM digestibility observed during the rainy season would be an imbalance concerning the metabolizable protein/metabolizable energy ratio, and even promoting apparently appropriate gains to the animals, it would impede maximization of pasture use. Thus, protein supplementation would adjust the synchronism in these protein and energy relations in the rumen environment and provide weight gains to supplemented animals.

Based on the average intake of enriched mineral supplement during this phase (rainy period) (Figure 5; 0.8 $\mathrm{g} / \mathrm{kg}$ body weight) and on the composition of the supplement utilized (198.9 g/kg CP; Table 1), we can assume that the increase in CP in the diet of the animals was on average $44.5 \mathrm{~g} / \mathrm{day}$. Along with this, evaluating the equations of $\mathrm{CP}$ requirement determined by Marcondes et al. (2010) for intact grazing Nellore males and considering that in that period these animals had average weight of $288.4 \mathrm{~kg}$, we understand that $52.7 \mathrm{~g} /$ day $\mathrm{CP}$ would be necessary for the accrual observed in weight gain ( 0.696 to $0.800 \mathrm{~kg}$ /day). Thus, based on the requirements of the animals and on the increase in daily protein intake promoted by supplementation, the gains achieved cannot be explained only by increase in protein.

This difference observed can possibly be explained by the combined action of protein supplementation and presence of additives in the diet, wherein the addition of salinomycin generated a positive interaction effect in relation to animal performance given the consumption of protein supplement plus pasture. This increase observed in the gain potential promoted by the action of the ionophore is explained by the improvement in feed efficiency, which is a reflection of selection in favor of propionate-producing bacteria.

Some researchers have reported the beneficial effects of ionophores, such as improvement in the metabolic efficiency of energy, modifying the proportion of volatile fatty acids produced in the rumen by increasing the concentration of propionate and reducing the concentrations of acetate and butyrate, with decrease in energy loss in the form of methane
(Bergen \& Bates, 1984; Bagg, 1997). Other effects such as reduction in degradation of dietary protein, increasing the amount of food-origin protein which reaches the small intestine can also be observed (Russel, 1987; Russel \& Strobel, 1989; Russel \& Wallace, 1997; Nagajara et al., 1997), which is another point for understanding the effect of the ionophore on the superior weight gain of animals fed enriched mineral supplement.

Evaluating the periods of the rainy season, the best weight gains were observed in the second phase: 0.876 $\mathrm{kg}$ /day in relation to gains of 0.733 and $0.634 \mathrm{~kg}$ /day in the third and first periods, respectively. The second period of the rainy season $(01 / 14 / 09$ to $02 / 18 / 09)$ was when the wet pasture was established, since the smallest variation in the data on sward structure composition occurred in this period (Figure 2). The smallest alterations of the sward components were observed in this period, mainly in relation to green leaves: 398.7 at the beginning and $382.7 \mathrm{~g} / \mathrm{kg} \mathrm{DM}$ at the end (Table 2). This remarkable characteristic, of lower oscillation in the way the forage is presented to the animal, results in consumption of a material of good quality all through the period.

In the third period of the rainy season $(02 / 18 / 09$ to $03 / 26 / 09)$, with the decrease in the number of green leaves (383.7 to $275.6 \mathrm{~g} / \mathrm{kg} \mathrm{DM}$ ), animal performance also decreased; in the first period (12/10/08 to $01 / 14 / 09)$ there was increase in the percentage of green leaves; however, its variation was very high (Figure 2), and this period had the lowest weight gain observed during the rainy season.

When the data on weight variation and a forage trait are discussed, the values are analyzed it their absolute form, i.e., the average of a given evaluation time. However, the weight gain of that period (interval between two successive assessments) is the result of the intensity of variation, especially of the pasture within the period studied, and how this variation occurs is extremely important for the interpretation of results. In the present study, analyzing the results obtained with simulated grazing (Table 4), it is impossible to explain the differences obtained in weight gain; however, observing the variation in the situation of the pasture (Figure 4) from which it was obtained, it is easier to view the pasture condition in the period.

Much has been discussed about the percentage of green leaves, since it is the main component of the diet of the animal and its availability is determinant for intake, and also the quality of the material consumed. Comparing the chemical composition of the whole plant and the results obtained with simulated grazing, we can acknowledge the capacity of the animals to select their diet (Figure 4), stressing their selective capacity. 


\section{Conclusions}

Low-intake enriched mineral supplementation allows for increases in the weight gain of animals kept under a grazing regime of $15 \%$ since there is no limitation in the amount of basal diet as was observed during the dry period. In the dry period, when forage is deficient in protein, supplementation with non-protein nitrogen is sufficient to attain low weight gain, from 0.100 to $0.300 \mathrm{~kg}$ /day. In the rainy period the interaction obtained with enriched mineral supplementation with addition of protein and growth promoters to the diet results in increased animal performance.

\section{Acknowledgements}

To Bellman Nutrição Animal for the partnership and for supplying the supplements utilized in this project and to Fundação de Amparo à Pesquisa do Estado de São Paulo - FAPESP, for the fellowship grant.

\section{References}

BAGG, R. Model of action of ionophores in lactating dairy cattle. Usefulness of ionophores in lactating dairy cattle. In: SYMPOSIUM HELD, 1997, Ontario. Proceedings... Ontario: Ontario Veterinary College, 1997. p.13-21.

BALSALOBRE, M.A.A.; CORSI, M.; SANTOS, P.M. et al. Composição química e fracionamento do nitrogênio e dos carboidratos do capim-Tanzânia irrigado sob três níveis de resíduo pós-pastejo. Revista Brasileira de Zootecnia, v.32, p.519-528, 2003.

BERGEN, W.G.; BATES, D.B. Ionophores: Their effect on production efficiency and mode of action. Journal of Animal Science, v.58, p.1465-1483, 1984.

CARVALHOFILHO, O.M.; CORSI, M.; CAMARÃO,A.P. Composição botânica da forragem disponível selecionada por novilhos fistulados no esôfago em pastagem de colonião - soja perene. Pesquisa Agropecuária Brasileira, v.19, p.511-518, 1984.

DESCHAMPS, F.C. Implicações do período de crescimento na composição química e digestão dos tecidos de cultivares de capim elefante. Revista Brasileira de Zootecnia, v.28, p.1178-1189, 1999.

DETMANN, E.; PAULINO, M.F.; MANTOVANI, H.C. et al. Parameterization of ruminal fibre degradation in low-quality tropical forage using Michaelis-Menten kinetics. Livestock Science, v.126, p.136-146, 2009.

GOERING, H.K.; VAN SOEST, P.J. Forage fiber analysis (Apparatus, reagents, procedures and some applications).
Washington, D.C.: Agriculture Research Service USDA, 1970. 20p. (Agricultural Handbook, 379).

GOES, R.H.T.B.; MANCIO, A.B.; LANA, R.P. et al. Recria de novilhos mestiços em pastagens de Brachiaria brizantha, com diferentes níveis de suplementação, na região Amazônica. Desempenho animal. Revista Brasileira de Zootecnia, v.34, p.1740-1750, 2005.

MARCONDES, M.I.; GIONBELLI, M.P.; VALADARES FILHO, S.C. et al. Exigências nutricionais de proteína para bovinos de corte. In: VALADARES FILHO, S.C.; MARCONDES, M.I.; CHIZZOTTI, M.L. et al. (Eds.). Exigências nutricionais de zebuínos puros e cruzados BR-Corte. 2.ed. Viçosa, MG: UFV, DZO, 2010. 193p.

MOTT, G.O.; LUCAS, H.L. The design, conduct and interpretation of grazing trials on cultivated an improved pastures. In: INTERNATIONAL GRASSLAND CONGRESS, 6., 1952. Pennsylvania. Proceedings... Pennsylvania: State College Press, 1952. p.1380-1385.

NAGARAJA, T.G.; NEWBOLD, C.J.; VAN NEVEL, C.J. et al. Manipulation of ruminal fermentation. In: HOBSON, P.N.; STEWART, C.S. (Eds). The rumen microbial ecosystem. London: Blackie Academic and professional, 1997. p.523-632.

REIS, R.A.; TEIXEIRA, I.A.M.A.; SIQUEIRA, G.R. Impacto da Qualidade da Forragem na Produção Animal. In: REUNIÃO ANUAL DA SOCIEDADE BRASILEIRA DE ZOOTECNIA, 43., 2006, João Pessoa. Anais... João Pessoa, 2006. (CD-ROM).

RUSSEL, J.B.; STROBEL, H.J. Mini-review: the effect of ionophores on ruminal fermentation. Applied and Environmental Microbiology, v.55, p.1, 1989.

RUSSEL, J.B.; WALLACE, R.J. Energy-yielding and energyconsuming reactions. In: HOBSON, P.N.; STEWART, C.S. (Eds). The rumen microbial ecosystem. 2.ed. London: Blackie Academic e Professional, 1997. p.246-282.

RUSSEL, J.B. A proposed model of monensina action in inhibiting rumen bacterial growth: effects on ion flux and proton motive force. Journal of Animal Science, v.64, p.1519, 1987.

SANTOS, M.E.R.; FONSECA, D.M.; EUCLIDES, V.P.B. et al. Valor nutritivo da forragem e de seus componentes morfológicos em pastagens de Brachiaria decumbens diferida. Boletim da Indústria Animal, v.65, p.303-311, 2008.

SANTOS, M.E.R.; FONSECA, D.M.; GOMES, V.M. et al. Estrutura do capim-braquiária durante o diferimento da pastagem. Acta Animal Science, v.32, p.139-145, 2010.

SILVA, D.J.; QUEIROZ, A.C. Análises de alimentos: métodos químicos e biológicos. 3.ed. Viçosa, MG: Imprensa Universitária da UFV, 2002. 165p.

SNIFFEN, C.J.; O'CONNOR, J. D.; VAN SOEST, P.J. et al. A net carbohydrate and protein system for evaluating cattle diets: II. Carbohydrate and protein availability. Journal of Animal Science, v.70, p.3562-3577. 1992.

SOLLENBERGER, L.E.; CHERNEY, D.J.R. Evaluating forage production and quality. In: BARNES, R.F.; MILLER, D.A.; NELSON, C.J. (Eds.). Forages: The science of grassland agriculture. Ames: Iowa State University Press, 1995. v.2, p.97-110.

VAN SOEST, P. J.; ROBERTSON, J. B.; LEWIS, B. A. Methods for dietary fiber, and nonstarch polysaccharides in relation to animal nutrition. Journal of Dairy Science, v.74, p.3583-3597, 1991. 